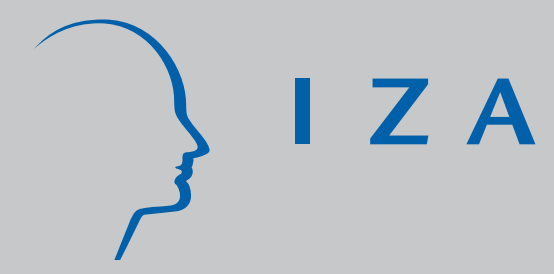

IZADP No. 2958

Globalization and Income Inequality

Elena Meschi

Marco Vivarelli

July 2007 


\title{
Globalization and Income Inequality
}

\author{
Elena Meschi \\ Marche Polytechnic University, Ancona \\ and CSGR Warwick \\ Marco Vivarelli \\ Catholic University of Milan, CSGR Warwick, \\ IPTS (European Commission, Seville) and IZA
}

\section{Discussion Paper No. 2958 \\ July 2007}

IZA

P.O. Box 7240

53072 Bonn

Germany

Phone: +49-228-3894-0

Fax: +49-228-3894-180

E-mail: iza@iza.org

Any opinions expressed here are those of the author(s) and not those of the institute. Research disseminated by IZA may include views on policy, but the institute itself takes no institutional policy positions.

The Institute for the Study of Labor (IZA) in Bonn is a local and virtual international research center and a place of communication between science, politics and business. IZA is an independent nonprofit company supported by Deutsche Post World Net. The center is associated with the University of Bonn and offers a stimulating research environment through its research networks, research support, and visitors and doctoral programs. IZA engages in (i) original and internationally competitive research in all fields of labor economics, (ii) development of policy concepts, and (iii) dissemination of research results and concepts to the interested public.

IZA Discussion Papers often represent preliminary work and are circulated to encourage discussion. Citation of such a paper should account for its provisional character. A revised version may be available directly from the author. 


\section{ABSTRACT}

\section{Globalization and Income Inequality}

This paper discusses the distributive consequences of trade flows in developing countries (DCs). On the theoretical side, we argue that the interplays between international openness and technology adoption may constitute an important mechanism leading to a possible increase of income differentials in the liberalizing DCs, trough skill enhancing trade. We use a dynamic specification to estimate the impact of trade on within-country income inequality in a sample of 70 DCs over the 1980-1999 period. Our results suggest that total aggregate trade flows are weakly related with income inequality. However, once we disaggregate total trade flows according to their areas of origin/destination, we find that trade with high income countries worsen income distribution in DCs, both through imports and exports. This finding provides a preliminary support to the hypothesis that technological differentials between trading partners are important in shaping the distributive effects of trade openness. Moreover, after testing for the differential impact of trade in middle income DCs vs low income ones, we observe that the previous result only holds for middle income countries (MICs). We interpret this evidence by considering the greater potential for technological upgrading in MICs both in terms of their higher "absorptive capacity" and in terms of their superior ability in serving the differentiated and high-quality markets of the developed world.

JEL Classification: F16, O15, O33

Keywords: globalization, within-country income distribution, technology transfer, developing countries, LSDVC estimator

Corresponding author:

Marco Vivarelli

Facoltà di Economia

Università Cattolica

Via Emilia Parmense 84

I-29100 Piacenza

Italy

E-mail: marco.vivarelli@unicatt.it

\footnotetext{
* Previous versions of this paper have been presented at the University of Ancona, at the University of Siena (Inequality Summer School, Siena, 17-24 June 2007) and at the 16th National Scientific Conference of the Italian Association for Comparative Economics (AISSEC, Parma, 21-23 June 2007); we wish to thank the discussant Paolo Piacentini and all the participants for their useful comments and suggestions. Precious insights by Mariacristina Piva are also gratefully acknowledged.
} 


\section{Introduction}

Since the beginning of the '80s, several developing countries (DCs) have followed the path of trade liberalization and have opened their economies towards international markets. Although the actual patterns of this process have differed across regions, on the whole trade flows have significantly increased over the last three decades and the diffusion of technology between countries has become more rapid and widespread.

Whether such a process of globalization is associated with narrowing or widening income disparities within developing countries is a matter of controversy in the economic literature. The standard trade theory, expressed in the Heckscher-Ohlin model, predicts that DCs should experience egalitarian trends as a consequence of globalization. One of the most important corollaries of Heckscher-Ohlin's model (HO) is the Stolper-Samuelson (SS) theorem. According to this main building-block of the theory of international trade, openness will benefit a country's relatively abundant factor, since trade specialization will favor sectors intensive in the abundant factor. Taking into account that most DCs - when compared with the world economy - are relatively abundant in unskilled labor and so have a comparative advantage in this production factor, openness should increase the demand for the unskilled workers and their wages, so ending up with an overall decrease in wage dispersion and within-country income inequality (WCII).

However, if the basic dichotomic framework depicted by the HOSS framework is extended to account for multiple skill-related categories of workers (Wood, 1994), country groups (Davis, 1996) and traded goods (Feenstra and Hanson, 1996), the main distributive prediction of the HOSS theory is theoretically undetermined and depends on the relative weights and directions of trade flows. Moreover, if the HOSS assumption of homogeneous production functions ${ }^{1}$ among countries is relaxed, then international openness may facilitate technology diffusion from High Income Countries to Low and Middle Income (LICs and MICs) ones, and it is very likely that the new technologies are more skill intensive in relation to those in use domestically before trade liberalization. If such is the case, then openness - via technology - should imply a counter-effect 
to the HOSS theorem prediction, namely an increase in the demand for skilled labor, an increase in wage dispersion and so an increase in income inequality (see Lee and Vivarelli, 2004 and 2006b).

This paper contributes to this literature by presenting new empirical results based on a unique dataset including 70 developing countries over the 1980-1999 period. Indeed, the first novelty of this paper is the use of a global inequality dataset - the UTIP-UNIDO database - which has been made available very recently and which ensures data comparability both through time and across countries (see section 4).

The second novelty of this paper regards the econometric specification and the estimation technique. Given the revealed persistence of the within-country inequality indexes, we use a dynamic specification (the lagged dependent variable is included as an explanatory variable) which allows us to account for the path-dependent nature of the distributional pattern. The resulting endogeneity problem is addressed by using a Least Squares Dummy Variable Corrected (LSDVC) estimator, a recently-proposed panel data technique particularly suitable for small samples.

Finally, we disentangle import and export flows according to their origin/destination areas. Our results show that both imports and exports from/to industrialized countries (ICs) significantly worsen income distribution in MICs. We interpret these findings by considering the interactions between a country's economic integration and its technological upgrading.

The remainder of the paper is organized as follows: in section 2 we critically discuss the arguments in favor of the alleged egalitarian impact of trade on within-country income inequality, mainly from a theoretical point of view. Section 3 presents the empirical model and explains the econometric specification. Section 4 describes the data and shows some descriptive statistics. Section 5 presents and discusses the results, while conclusive statements are derived in Section 6. 


\section{The literature}

The standard model used by economists to analyze the effect of trade on the relative returns to different factors of production is the $\mathrm{HO}$ model, which builds on the Ricardian theory of comparative advantages by predicting patterns of trade and production based on the factor endowment of a trading region. In its simplest version, as reported in Wood (1994), the model assumes two factors of production - skilled and unskilled labor - and two countries, the North (developed countries) and the South (developing countries), each producing two goods (skilled and unskilled labor-intensive) ${ }^{2}$. The related predictions in terms of the distributive consequences of trade openness are well known and have often been invoked to justify trade liberalization in the DCs: greater openness should increase the relative demand and prices for unskilled labor and lead to a more equal distribution of wages in low-skilled-labor abundant countries. However, some important critiques have been made of this HOSS theoretical framework. In particular, it is argued that the $\mathrm{HO}$ model and the SS theorem are based on several assumptions that are too restrictive to describe the real world ${ }^{3}$. In fact, if the model is extended to account for many countries characterized by different technologies, then the distributional consequences of trade become unpredictable and may differ from those one would anticipate on the basis of a simplistic North-South interpretation of the SS theorem. In the next paragraphs, we discuss the implications arising if some assumptions of the model are relaxed.

\section{1: Global or local validity of the SS theorem?}

Even retaining the central assumptions of the HO model, what matters for the distributive consequences of trade liberalization is the relative position of a given country amongst the other countries within its own 'cone of diversification' (Davis, 1996). In fact, a developing country may be considered as "unskilled abundant" in global terms, but this may not be true in relation to other DCs. If factor abundance is defined in a local sense, the distributional consequences of trade can be the exact opposite of what we expect in a traditional HOSS framework (Davis, 1996). 
This argument is particularly important for middle-income countries (MIC) which are likely to be relatively unskilled-labor-abundant in comparison with high-income trading partners and relatively skilled-labor-abundant in comparison with low-income ones. Thus, when MICs open to trade, they have to face the competition of labor-intensive manufacturing from low-wage, labor abundant low-income countries, and this can change their comparative advantages in labor intensive exports ${ }^{4}$, possibly resulting in a decrease in demand and wages for unskilled workers and in a wider wage gap.

Feenstra and Hanson $(1996,1997)$ push this argument a step further and propose a model where there is a continuum of goods ordered along a ladder whose steps are characterized by different levels of skill intensity. The model assumes the production of a simple final good that requires a continuum of intermediary goods with varying proportions of skilled and unskilled labor. They assume that the developing region has a comparative advantage in the unskilled labor intensive stages of the production, whilst the developed region is more efficient in the skilled labor intensive parts. Trade liberalization would shift the production of intermediate inputs (through trade and foreign direct investment) form developed to developing countries. While such products would be characterized as unskilled-labor-intensive from a developed country's perspective, they appear to be skilled-labor-intensive from a developing country's point of view. In this way, average skill intensity and therefore the demand for skilled labor increase both in the North and in the South, inducing a rise in the skill premium in both areas. Zhu and Trefler (2005) have extended Feenstra and Hanson's model to a case without foreign direct investment but with a Ricardian source of comparative advantage added to that based on factor endowment. In their model, technological catch-up by the developing country causes a shift in production of the least skill-intensive Northern goods to Southern countries where they become the most skill-intensive goods produced. This mechanism, similar to the one proposed by Feenstra and Hanson, leads to a rise in the demand for skilled labor in both developed and developing countries. Xu (2003) has also developed a model with a continum of goods where the boundary between traded and non- 
traded goods is endogenous and determined by trade policy. He shows that trade liberalisation by expanding a developing country's export set can raise wage inequality.

\section{2: The role of technology}

If the hypothesis of identical technologies among countries is dropped and one assumes that developed countries and DCs differ in their technology levels ${ }^{5}$ and that openness facilitates technology diffusion from North to South, then the final impact of trade in terms of demand for labor also depends on the skill intensity of the transferred technology relative to that currently in use. There are many empirical studies showing the skill-biased nature of technological change in the developed economies (see, for instance, Berman et al. 1994; Autor et al. 1998; Machin and Van Reenen, 1998). Without necessarily assuming that developed countries transfer their "best" technologies to the DCs, it is quite reasonable to expect that transferred technologies are relatively skill-intensive, i.e. more skill-intensive than those in use domestically before trade liberalization. Indeed, to the extent that technology upgrading is linked to international openness, trade liberalization may increase the demand for skilled labor in developing countries too, reversing the prediction of the SS theorem ${ }^{6}$.

\subsection{1: The import channel}

Trade liberalization favors technological upgrading by increasing international flows of capital goods. As long as capital goods incorporate new technologies, the increase in imports of machinery and equipment should help technological diffusion among DCs and raise their relative demand for skilled labor (Acemoglu, 2003). There is much literature that finds that import flows can in fact contribute to the international transfer of technology by providing DCs' local firms access to new embodied technologies and by creating opportunities for reverse engineering.

Coe and Helpman (1995), studying a sample of OECD countries, find that foreign knowledge embodied in traded goods ${ }^{7}$ has a statistically significant positive impact on aggregate total factor 
productivity (TFP) in importing countries. Coe et al. (1997) have extended the analysis to DCs and show that imports of intermediate goods raise the TFP in DCs as well. Moreover, Mayer (2000) restricts the definition of import shares by considering only machinery and finds that in this case the impact of foreign R\&D is much greater. Schiff and Wang (2006) underline how trade-related technology diffusion can occur through an increase in a country's level of exposure to that technology through trade (quantity), or through an increase in the knowledge content of that trade (quality). The distinction between the quality and quantity of new technologies is further analyzed by Barba-Navaretti and Solaga (2002), who look at the role of imported machinery in transferring embodied technological progress. Their study focuses on the imports of machines from the EU to a sample of neighboring developing and transition countries in Central-Eastern Europe and in the Southern Mediterranean. They find that imported machinery has a positive impact on total factor productivity and that the impact is greater the higher the technological complexity of imported machinery ${ }^{8}$. Other studies used firm level database to examine imports as a mechanism for technological transfer and find that imports can in fact improve firm technological capabilities (see for example, Blalock and Veloso, 2007).

Robbins (1996 and 2003) has called the effect of in-flowing technology resulting from trade liberalization the 'skill-enhancing trade (SET) hypothesis'. His idea is that trade liberalization accelerates the flows of physical capital (and embodied technology) to the South, inducing rapid adaptation to the modern skill-intensive technologies currently used in the North. The resulting increased demand for skilled labor may then lead to a widening of wage and income dispersion in developing countries.

\subsection{2: The export channel}

Breaking into foreign markets allows firms to acquire knowledge of international best practice. Moreover, foreign buyers often provide their suppliers with technical assistance and product design in order to improve the quality of imported goods, and they may transmit to their 
suppliers located in DCs the tacit knowledge acquired from other suppliers located in advanced countries (Epifani, 2003).

Yeaple (2005) shows that increased export opportunities make the adoption of new technologies profitable for more firms, thus increasing the aggregate demand for skilled labor and the skill premium. Bustos (2005) builds a model upon the works of Yeaple (2005) and Melitz (2003), arguing that trade liberalization reduces variable export costs, increasing exporting revenues and inducing more firms to enter the export market, which makes adoption of new technologies profitable for more firms. Adoption of skill-intensive new technologies increases the relative demand for skilled labor and the skill premium. She uses this framework to explain the increase in wage inequality experienced by Argentina after trade liberalization.

A different mechanism of skill upgrading in exporting plants is discussed by Verhoogen (2007), who argues that trade openness leads to an upgrading of average product quality in exporting plants, which in turn generates demand for a better qualified workforce. He finds that the "quality-upgrading hypothesis" is more relevant than the "outsourcing hypothesis" as an explanation for increasing wage inequality in Mexico. This idea is also pursued by Fajnzylber and Fernandes (2004), who point out that exporters may be pressured by their foreign clients to produce according to quality standards that are higher than those prevailing in the domestic market. In fact, they find that exports had a positive impact in the relative demand for skills in Brazil. Other evidence for the inequality-enhancing role of exports can be found in Hanson and Harrison (1999), who document that exporting firms employ a higher share of white-collar workers than non-exporting plants in Mexico?.

\section{3: Previous empirical evidence}

On the whole, relaxing the HO hypothesis of technological homogeneity and allowing for capital deepening and skill-biased technological change (SBTC) opens the way to important 
possible counter-effects in terms of the distributional impact of globalization. In such a framework, increasing openness may raise the relative wages of skilled labor and consequently income inequality in both developed and developing countries.

The hypothesis of the 'pervasiveness' of SBTC has recently been confirmed empirically by Berman and Machin (2000 and 2004), who find strong evidence for an increased demand for skills - at least for manufacturing sectors of middle-income DCs in the $80 \mathrm{~s}^{10}$ - and relate it to skill-biased technology absorption. The authors find that skill-upgrading is predominantly a within-industry phenomenon, that it is concentrated in the same industries across countries, and that DCs' indicators are highly correlated with those for OECD countries. Their results seem to suggest that SBTC has in fact been transferred from the developed world to middle income countries and support the pervasive nature of SBTC.

Conte and Vivarelli (2007) have studied the impact of technological transfer on the employment of skilled and unskilled labor in a sample of low and middle income countries. By using a direct measure of embodied technological transfer - namely the trade flows from industrialized countries of those goods which reasonably incorporate technological upgrading they have found that imported skill-biased technological change is in fact one of the determinants of the increase in the relative demand for skilled workers within DCs in the ' 80 s.

These works suggest a role for technology in explaining the increased demand for skilled labor in DCs. However, they do not deal directly with income distribution. The empirical literature explicitly treating the impact of international trade on WCII is heterogeneous and fails to reach a consensus.

On the one hand, an increasing number of country-specific empirical works show that the intensification of trade flows is frequently associated with an increase in the relative demand for skilled labor and a consequent rise in the skill premium ${ }^{11}$.

On the other hand, the evidence arising from multi-country empirical works is mixed and the conclusions often depend on the specification adopted and the measurement of the variables of 
interest $^{12}$. However, this literature reveals that only a few empirical studies unambiguously support the predictions of the Stolper-Samuelson theorem and document a decrease in income inequality after trade liberalization. These include Wood (1994), Bourguignon and Morrisson (1990), Calderón and Chong (2001) and Dollar and Kraay (2004). The majority of cross-country studies, instead, either do not register any significant and systematic relationship between openness and income distribution (see e.g. Edwards, 1997; Li, Squire and Zou, 1998 and Vivarelli, 2004), or clearly contradict the distributive outcomes of traditional trade theory. For instance, Barro (2000), Ravallion (2001), Cornia and Kiiski (2001), Lundberg and Squire (2003), Easterly (2005) and Milanovic and Squire (2005) have shown that in their samples trade liberalization is associated with an increase in income inequality.

Many of these works are characterized by a cross-section (or short panel) methodology and hence the between-country dimension of inequality is dominant. In contrast, this paper will focus on WCII, which is even more important from a policy perspective. In fact, WCII trends are crucial in terms of social cohesion and political stability and may be considered a possible target for national economic policies. Moreover, while population-weighted between-country inequality has shown a declining historical trend, the opposite has emerged as far as the within-country component of income distribution is concerned (see Sala-i-Martin, 2002).

\section{The empirical model}

As we underlined in section 2, most previous works studying the relationship between trade openness and income distribution used cross sectional analysis. In contrast, this paper adopts a dynamic specification which takes countries' unobserved heterogeneity fully into account.

\section{1: The tested specification}

The adoption of a dynamic specification is motivated by two reasons. From an econometric point of view, the revealed persistence of the inequality variable $(\varrho=0.834)^{13}$ calls for a necessary 
AR(1) check. From an interpretative point of view, the lagged value of the dependent variable can account for the path-dependent and viscous nature of inequality, which is affected by a number of structural factors that are very slow to change, such as institutional context, factor endowments, land and asset distribution, urbanization, etc.

Therefore, the proposed empirical specification will be the following:

$$
E H I I_{i t}=\alpha+\rho E H I I_{i, t-1}+\beta \text { OPEN }_{i t}+\sum_{k} \delta_{k} X_{i k t}+\eta_{i}+\varepsilon_{i t}
$$

where $i$ and $t$ denote country and time period, respectively. EHII is the estimated household income inequality (see section 4); OPEN is the openness variable (alternatively: total trade, imports and exports); $X_{K}$ are a set of control variables; $\eta_{i}$ is the idiosyncratic individual and time-invariant country's fixed effect and $\varepsilon_{i t}$ the usual error term. All variables are expressed in natural logarithms.

Although our dynamic specification permits us to ignore time invariant factors, we still have to include some controls which change over time.

First, the dynamics of within-country income inequality can be affected by per-capita GDP levels, that is by the stage of development of a given economic system. According to Kuznets (1955), the relationship between inequality and economic development follows an inverted-U pattern with inequality rising at the initial stages of development and then falling. The basic idea under Kuznets' demand-pull model is that - during the initial stages of development - growth in demand spurs labor-saving technological change favoring the demand for capital and skills, so increasing income inequality. Eventually, as catching-up proceeds, the labor-saving tendency attenuates and more egalitarian forces, such as an increase in education (and so in the supply of skilled labor), are allowed to have their impact (for recent revisitings of Kuznets' law, see Aghion and Howitt, 1997; Barro, 2000; Grimalda and Vivarelli, 2004). 
Second, education should also be taken into account. An increase in education implies an increase in the supply of skilled labor, a decrease in the relative skilled/unskilled wage differential and an overall decrease in income inequality. A steady increase in the supply of skilled labor might keep the relative skilled/unskilled wages constant, even in the presence of skill-biased technological change. Therefore it is important to include a proxy for the educational level in the estimating equation.

Finally, we include the inflation rate in the model, to check for the macroeconomic environment which is likely to affect income distribution. This aspect is particularly important in developing countries, often characterized by highly instable macroeconomic conditions. Inflation erodes real wages and disproportionately affects those within the bottom percentiles of income distribution, thus increasing inequality. A number of papers find that high inflation is in fact associated with higher inequality (see for example, Lundberg and Squire, 2003 and De Melo et al., 2006).

\section{2: The econometric method}

The inclusion of the lagged dependent variable as one of the regressors in (1) implies an obvious problem of endogeneity. A natural solution for first-order dynamic panel data models is to use GMM (General Method of Moments; see Arellano and Bond, 1991; Blundell and Bond, 1998). Unfortunately, this method is only efficient asymptotically and is not suitable for small samples. In our case, we only have 70 countries, observed over 20 years and hence the GMM designed for "small T and large N" may not be appropriate. Therefore we use the LSDVC ${ }^{14}$ estimator, a method recently proposed by Kiviet (1995), Judson and Owen (1999), Bun and Kiviet (2003) and extended by Bruno (2005) to unbalanced panels such as the one used in this study. This method has been proposed precisely as a suitable dynamic panel data technique in the case of small samples where GMM cannot be applied efficiently ${ }^{15}$. Let us suppose we have a 
standard autoregressive panel data model, based on the possibility of collecting observations over time and across individuals; our problem can then be described as follows:

(2) $y=D \eta+W \delta+v$

where $y$ is the vector of observations for the dependent variable, $D$ is the matrix of individual dummies, $\eta$ is the vector of individual effects, $W$ is the matrix of explanatory variables including the lagged dependent variable, $\delta$ is the vector of coefficients, and $v$ the usual error term. The Least Square Dummy Variable (LSDV) estimator is the following:

(3) $\delta_{L S D V}=\left(W^{\prime} A W\right)^{-1} W^{\prime} A y$

where $A$ is the within transformation which wipes out the individual effects.

Since the LSDV estimator is not consistent when the lagged dependent variable enters into the model, a more accurate measuring of its bias can be seen as the first step towards correcting it. The LSDV bias is given by:

(4) $\quad E\left(\delta_{L S D V}-\delta\right)=c_{1}\left(T^{-1}\right)+c_{2}\left(N^{-1} T^{-1}\right)+c_{3}\left(N^{-1} T^{-2}\right)+O\left(N^{-2} T^{-2}\right)$

For the analytical expression of the terms in formula (4) see Bun and Kiviet (2003, p.147).

In their Monte Carlo simulations, Bun e Kiviet (2003) and Bruno (2005) consider three possible nested approximations of the LSDV bias, which in turn are extended to the first, second and third terms of $(4)^{16}$. In this study we will correct for the most comprehensive and accurate one $\left(\mathrm{B}_{3}\right)$ in their notation). Therefore, in the following, the LSDVC estimator is equal to:

(5) $L S D V C=L S D V-B_{3}$ 
The procedure has to be initialized by a consistent estimator to make the correction feasible, since the bias approximation depends on the unknown population parameters. Three possible options for this purpose are the Anderson-Hsiao, Arellano-Bond and Blundell-Bond estimators. In this study, we initialize the bias correction with the Arellano-Bond estimator, here considered as the best established panel data estimator implemented in the STATA econometric package used $^{17}$.

Finally, the estimated asymptotic standard errors may provide poor approximations in small samples, generating possibly unreliable t-statistics, while bootstrap methods generally provide approximations to the sampling distribution of statistics which are at least as accurate as approximations based upon first-order asymptotic assumptions. Accordingly, in this study the statistical significance of the LSDVC coefficients has been tested using bootstrapped standard errors (200 iterations).

\section{Data and descriptive statistics}

The empirical analysis in this paper makes use of a time-series/cross-country dataset that provides comparable and consistent measurements of income inequality both across countries and through time. This database was created by Galbraith and associates, and is known as the University of Texas Inequality Project (UTIP) database ${ }^{18}$. It contains two different types of data on inequality: the UTIP-UNIDO and the EHII indexes. The UTIP-UNIDO is a set of measures of the dispersion of manufacturing payments, built using the between-groups component of a Theil index measured across industrial categories ${ }^{19}$ (see Galbraith and Kum, 2003). The EHII is an index (ranging from 0 to 1 as a conventional Gini index) of Estimated Household Income Inequality and is built combining the information in the Deninger and Squire $(D \& S)^{20}$ data with the information in the UTIP-UNIDO data. The D\&S database is the standard reference for inequality studies; however, the coverage of the D\&S is sparse and unbalanced, and consequently 
its measures of inequality originate from different sources and refer to a variety of income and population definitions ${ }^{21}$. For instance, many cross-country studies on inequality have used the D\&S-based World Income Inequality Database (WIID) ${ }^{22}$. Indeed, the Gini coefficients in WIID are based on different income definitions (income/expenditure; gross/net), different recipient units (individuals/households) and population coverage (urban/rural/all). Even when adjustments are made to improve data comparability ${ }^{23}$, these differences may still result in serious data inconsistency. This poses important problems of comparability which may undermine the robustness of the results. Instead, the EHII - based on the consistent UTIP-UNIDO data overcome such comparability problems.

The EHII is in fact built following a two-step procedure. First, the D\&S Gini coefficients are regressed on the UTIP-UNIDO measures of income dispersion, and on a matrix of conditioning variables including dummies for the three types of data source (income/expenditure; household/per capita; gross/net) ${ }^{24}$. Then EHII is computed using the same exogenous variables, where the intercept and coefficients are the deterministic parts extracted from the first-step estimation (see Galbraith and Kum, 2003, for a detailed explanation of this procedure).

The resulting EHII dataset is an unbalanced panel which contains more than 3,000 observations covering over 150 countries over the period 1963-1999. We restrict the sample to 70 developing countries over the 1980-1999 period. The choice of the countries is guided by the availability of data regarding the other variables we enter in the model, while the limitation of the time span to the 1980-99 period is due to economic and interpretative reasons: these are in fact the years when globalization - measured in terms of trade flows - registered a substantial increase in most DCs. Appendix 1 gives the complete list of countries, and reports the initial, final, and mean value of the EHII index in each country, as well as the change in the value of the index in the period considered. Figure 1 show the evolution of the EHII index over the sample period for the two groups of Middle Income (MIC) and Low Income (LIC) countries ${ }^{25}$.

INSERT FIGURE 1 
We observe a rising trend in the EHII index in both the series. However, inequality is higher in LICs where the average EHII index was around 45 in 1980 and almost reached 50 in 1999. In MIC inequality levels are lower, but they experienced a significant increase, especially in the decade going from the mid-80s to the mid-90s.

Data on total trade flows are taken from the IMF Direction of Trade Statistics (DOTS). This dataset provides aggregate data on imports and exports and also allows us to distinguish trade flows according to their origin/destination areas. In particular, we are interested in disaggregating trade flows with other DCs with respect to flows with Industrial Countries (IC).

Following Wood (1994) and Wood and Ridao-Cano (1999), our measure of skill supply (human capital $=\mathrm{HK}$ ) is built as the ratio between the percentage of the population with basic education and the percentage of the population with no education. When the number of educated people expands relative to the non-educated, we expect a decrease in income inequality. These data are gathered from the Barro-Lee database (See Barro and Lee, 1996 and 2001), which provides information on educational attainment over five-year intervals ${ }^{26}$. In order to match these data with our annual observations on inequality, we interpolated the data available, under the hypothesis that the yearly increase is constant over time for the missing periods. Other control variables, such as GDP per capita and the inflation rate ${ }^{27}$, are taken from the World Development Indicators (WDI) provided annually by the World Bank. In the next table summary statistics of the data included in the regressions are presented.

\section{INSERT TABLE 1 HERE}

\section{Results}

Table 2 displays the results for the baseline specification. Columns differ according to the openness variable included: trade ( $\%$ GDP) in columns $1 / 2$, imports $(\%$ GDP) and exports $(\%$ GDP) in columns $3 / 4$ and 5/6 respectively. In this and the following tables, the dynamic 
specification (1) has been tested using contemporaneous trade variables only and then their lag as well, in order to check for possible delayed impacts. Thus, the column with the contemporaneous impact is followed by a column also including the lagged impact together with the long term coefficient (LTI), the value and significance of which is reported in the bottom panel of the tables $^{28}$.

\section{INSERT TABLE 2 HERE}

As can be seen from table 2, contemporaneous trade and imports have a small and barely significant positive impact on WCII in the investigated DCs, while exports have no significant impact; moreover, both lagged and LTI coefficients - although positive - never turn out to be significant.

Inflation and the supply of education have the expected signs; an increase in the supply of skilled labor ${ }^{29}$ tends to diminish inequality, while higher inflation is associated with a worsening of income distribution. However, only the inflation coefficient is significantly different from zero. The impact of GDP per capita is also not significant; however, its negative sign seems to suggest a Kutznet's relationship in its second stage of development, when an increase in GDP leads to a reduction in inequality. Finally, as expected, the lagged dependent variable is always higher than 0.95 and largely significant ${ }^{30}$.

These findings confirm the results of previous empirical works which failed to envisage a strong and significant relationship between openness and within-country income inequality. However, the examination of total trade flows does not enable us to identify the mechanisms of transmission between international openness and income distribution precisely. As we stressed in section 2, the trade-induced transfer of technology may be an important factor affecting the distributional consequence of trade liberalization. When the developing countries open to trade, they become more exposed to technologies and innovations produced in more advanced countries. Hence, it is trade with richer countries which should involve technological upgrading, a 
general shift of labor demand towards more skilled workers, a consequent increase in wage differentials and so an increase in WCII. In other words, the insignificant (or barely significant) results emerging in table 2 may be affected by important composition effects which deserve further investigation.

Thus, we disaggregated trade flows according to their origin/destination areas, in order to test the possible inequality-enhancing effect of trade with richer countries, both through the import (see section 2.2.1) and the export channel (see section 2.2.2). Table 3 reports the results of this decomposition.

\section{INSERT TABLE 3 HERE}

The estimates reveal that trade, imports and exports with industrialized countries (ICs) are the only components of trade which worsen income distribution, whereas the same flows towards other developing countries either do not affect WCII or even exert an opposite effect. In more detail, contemporaneous estimates reveal a positive and significant role of total trade and exports with ICs in increasing WCII in the investigated DCs. While still positive, imports do not reach the statistically significant threshold. Once one year lags are taken into account, lagged impacts seem to prevail and the divide between flows with ICs and those within DCs becomes even more obvious: trade and imports with ICs worsen income distribution, while trade, imports and exports with other DCs have the opposite effect ${ }^{31}$. Overall, trade flows with ICs (either contemporaneous or lagged) positively and significantly impact on WCII, while lagged trade flows with other DCs exert an equalizing effect. The role of trade with ICs is confirmed by the positive signs of the LTI coefficients (although they never turn out to be significant at the conventional levels).

We interpret this evidence as a support for the hypothesis that technological differentials between trading partners play an important role in explaining the distributive impact of trade openness (see section 2). 
However, these results may be affected by another composition effect; in fact, pooling together MICs and LICs does not allow us to capture the distinctive features of the relationship between trade openness, technology upgrading and inequality in the two groups of countries. MICs and LICs may in fact be affected in different ways by international trade. Indeed, the potential for technological upgrading should be greater in MICs, which are more likely to be characterized by higher 'absorptive capacity' (or "capabilities"), which are considered a fundamental pre-requisite for taking advantage of new technologies (see, for instance, Abramovitz, 1986; Lall, 2004). This may in turn influence the choice of the technologies to import; in other words, MICs have the necessary capabilities in order to use the technologies produced in more advanced countries and to follow a catching-up pattern of development. While this process may have a positive impact on economic growth, it is very likely that it also implies an (at least temporary) increase in the demand and wages for skilled labor (at least until the labor supply adjusts as a result). In contrast, trade with LICs is often confined to the importation of older (or second-hand) capital equipment that requires fewer skills to operate than technologically updated equipment (Barba Navaretti et al., 1998 ${ }^{32}$ ). Therefore - as far as LICs are concerned - trade with more advanced countries may not have the same adverse consequences in terms of income distribution.

Turning the attention to the export side, MICs are better endowed with the industrial infrastructure needed to serve the sophisticated and demanding markets of the developed countries, so the skill-enhancing impact of exports is likely to affect only this group of counties. In contrast, exports from LICs are mainly concentrated in the primary and extractive sectors and are generally characterised by a low-technology content.

Therefore, we expect the inequality-enhancing effect of trade with more advanced economies to be stronger for MICs. We test this idea in table 4, where the openness indicators of table 3 are interacted with dummy variables indicating whether a developing country is middle income or 
low income. In this way, we are able to evaluate the differential impacts of the disaggregated trade flows into/from the two groups of countries.

\section{INSERT TABLE 4 HERE}

The results from the new final estimates support our hypothesis; interestingly, we note that the previous empirical findings only hold for middle income countries. As it can be noted, all the results from table 3 are confirmed both in terms of signs and significances, but only with regard to the variables interacted with MICs, while interactions with LICs never turn out to be significant. Moreover, long term impacts involving MICs always emerge as positive (and significant in the case of trade) ${ }^{33}$.

\section{Concluding remarks}

This paper has discussed the impact of trade flows on WCII in DCs. We have argued that the interplays between trade opening and technology adoption may constitute an important mechanism leading to a possible increase in income differentials in the liberalizing DCs.

Theoretically, if the HOSS assumption of identical technologies across countries is dropped, increasing exposure to international markets can foster the process of technology diffusion across DCs, through both imports and exports. The technologies transferred from more advanced countries are more skill-intensive with respect to those domestically in use and thus the tradeinduced technology upgrading may result in a labor demand shift in favor of skilled labor, ending in a generalized increase in the skill premium and hence in a more unequal income distribution.

We have used a dynamic specification to estimate the impact of trade on WCII in a sample of 70 DCs over the 1980-1999 period. Our results - consistently with previous evidence - suggest that total aggregate trade flows are positively but weakly related to WCII in DCs. However, we have moved a step forward, disaggregating total trade flows according to their areas of origin/destination, our hypothesis being that what should matter in terms of income inequality is 
not trade in general, but only trade with more advanced countries, where the potential for technology diffusion originates. Interestingly, we found that only trade with high income countries worsens income distribution in DCs, through both imports and exports (while a tentative evidence emerges showing a possible counterbalancing effect of trade within DCs). Having tested the differential impact of trade in middle income $v$ s low income countries, we then observed that the previous results only hold for MICs. We interpreted this evidence by considering the greater potential for technological upgrading in MICs, in terms of both their higher "absorptive capacity" and their superior ability to serve the differentiated and high-quality markets of the developed world.

\section{REFERENCES}

Abramovitz, M., (1986): "Catching-up, Forging Ahead and Falling Behind", Journal of Economic History, vol.46, pp.385-406

Acemoglu, D. (2003): “Patterns of Skill Premia”, Review of Economic Studies, Vol. 70; pp. 199-230.

Aghion, P. and Howitt, P. (1997): “Endogenous Economic Growth”, MIT Press, Cambridge (Mass.).

Alvarez, R. (2007): "Explaining Export Success: Firm Characteristics and Spillover Effects", World development, Vol. 35(3), pp. 377-393

Arbache, J.S., Dickerson, A. and Green, F. (2004): "Trade Liberalisation and Wages in Developing Countries", The Economic Journal, Vol. 114 (493), pp. F73-F96.

Arellano, M. and Bond, S. (1991): "Some Tests of Specification for Panel Data: Monte Carlo Evidence and an Application to Employment Equations”, Review of Economic Studies, vol.58, pp.277-97.

Atkinson, A. and Brandolini, A. (2001), "Promise and Pitfalls in the Use of Secondary Data-Sets: Income Inequality in OECD Countries as a Case Study", Journal of Economic Literature, Vol. (34), pp. 771-799.

Attanasio, O., Goldberg P., and Pavcnik, N. (2004): "Trade Reforms and Wage Inequality in Colombia," Journal of Development Economics 74; pp. 331-366.

Autor, D., Katz, L. and Krueger, A.B. (1998): “Computing Inequality: Have Computers Changed the Labor Market?” Quarterly Journal of Economics 113, pp: 1169-1214.

Barba Navaretti, G., Solaga, I and Takacs, W. (1998): "When Vintage Technology Makes Sense: Matching Imports to Skills", World Bank. Working Paper No.1923, World Bank, Washington, D.C. 
Barba Navaretti, G. and Solaga, I. (2002): "Weightless machines and costless knowledge - an empirical analysis of trade and technology diffusion", CEPR Discussion Paper N. 3321, Centre for Economic Policy Research, London.

Barro, R. (2000): "Inequality and Growth in a panel of countries", Journal of Economic Growth, Vol.5, pp. 5-32.

Barro, R. and Lee, J.W. (1996): "International measures of schooling years and schooling quality", American Economic Review Papers and Proceedings, Vol. 86(2), pp. 218-23.

Barro, R. and Lee, J.W. (2001): "International Data On Educational Attainment: Updates And Implications," Oxford Economic Papers, Vol. 53(3), pp. 541-563.

Bensidoun, I., Jean, S. and Sztulman, A. (2005): "International Trade and Income Distribution: Reconsidering the Evidence," CEPII Working Papers n17, CEPII, Paris.

Berman, E., Bound, J. and Griliches, Z. (1994): "Changes in the Demand for Skilled Labor Within U.S. Manufacturing Industries.” Quarterly Journal of Economics 109 pp: 367-398.

Berman, E. and Machin, S. (2000): "Skill-Biased Technology Transfer Around the World", Oxford Review of Economic Policy, Vol.16 (3), pp: 12-22.

Berman, E. and Machin, S. (2004): "Globalization, Skill-Biased Technological Change and Labour Demand", in Lee, E. and Vivarelli, M. (2004) (eds) "Understanding Globalization, Employment and Poverty Reduction", Palgrave Macmillan, New York, pp. 39-66.

Blalock, G. and Veloso, F.M (2007): “Imports, Productivity Growth, and Supply Chain Learning”, World Development, Vol. 35 (7), pp. 1134-1151.

Blundell, R. and Bond, S. (1998): "Initial conditions and moment restrictions in dynamic panel data models", Journal of Econometrics, vol. 87, pp. 115-43

Bourguignon, F., Morrisson, C. (1990): "Income distribution, development and foreign trade", European Economic Review, Vol. 34, pp. 1113-1132.

Bruno, G.S.F. (2005): “Approximating the Bias of the LSDV Estimator for Dynamic Unbalanced Panel Data Models”, Economics Letters, vol.87, pp.361-66.

Bun, M. J. G. and Kiviet, J. F. (2003): "On the diminishing returns of higher order terms in asymptotic expansions of bias", Economics Letters, vol. 79, 145-52

Bustos, P. (2005): “The Impact of Trade on Technology and Skill Upgrading: Evidence from Argentina”, mimeo, CREI and Universitat Pompeu Fabra, Barcelona.

Calderón, C. and Chong, A. (2001): "External sector and income inequality in interdependent economies using a dynamic panel data approach", Economics Letters, Vol. 71(2), pp. 225-231

Chamarbagwala, R. (2006): "Economic Liberalization and Wage Inequality in India", World Development, Vol. 34 (12), pp. 1997-2015

Cline, W.R. (1997): “Trade and Income Distribution”, Institute for International Economics, Washington, D.C.

Coe, D.T. and Helpman, E. (1995): "International R\&D Spillovers", European Economic Review, Vol. 39, pp. 859-887. 
Coe, D.T., E. Helpman and A. Homaister (1997): "North-South Spillovers," Economic Journal 107, pp.134149.

Conte, A. and Vivarelli, M. (2007): "Globalization and Employment: Imported Skill Biased Technological Change in Developing Countries", IZA Discussion Paper, N. 2797, IZA, Bonn.

Cornia, G.A. (2003): "The Impact of Liberalisation and Globalisation on Within-country Income Inequality", CESifo Economic Studies, Vol. 49 (4), pp. 581-616

Cornia, G.A. and Kiiski, S. (2001): "Trends in Income Distribution in the Post World War II Period: Evidence and Interpretation”, UNU/WIDER Discussion Papers 89, UNU/WIDER, Helsinki, Finland.

Cragg, M.I. and Epelbaum, M. (1996): "Why has wage dispersion grown in Mexico? Is it the incidence of reforms or the growing demand for skills?”, Journal of Development Economics, Vol. 51, pp. 99- 116.

Davis, D. (1996): “Trade Liberalization and Income Distribution”, NBER Working Paper, No.5693, National Bureau of Economic Research, Cambridge (Mass.)

Deininger, K. and Squire, L. (1996): “A New Data Set Measuring Income Inequality”, The World Bank Economic Review, vol.10, pp. 565-91.

De Melo, J., Gourdon, J. and Maystre, N. (2006): "Openness, Inequality and Poverty: Endowments Matter," CEPR Discussion Papers N. 5738, Centre for Economic Policy Research, London.

Dollar, D. and Kraay, A. (2004): "Trade, Growth, and Poverty", The Economic Journal, Vol. 114 (493), pp.F22-F49.

Easterly, W. (2005): "Globalization, Prosperity, and Poverty", in Ann Harrison (editor), "Globalization and Poverty”, forthcoming, University of Chicago Press for NBER.

Edwards, S. (1997): “Trade Policy, Growth, and Income Distribution”, The American Economic Review, Vol. 87 (2), Papers and Proceedings of the Hundred and Fourth Annual Meeting of the American Economic Association; pp. 205-210.

Epifani, P. (2003): "Trade liberalization, firm performance, and labor market outcomes in the developing world : what can we learn from micro-level data?," Policy Research Working Paper Series N. 3063, The World Bank, Washington DC.

Fajnzylber, P. and Fernandes, A. M. (2004): "International economic activities and the demand for skilled labor: evidence from Brazil and China," Policy Research Working Paper Series, N. 3426, The World Bank, Washington DC.

Feenstra, R. and Hanson, G. (1996): "Globalization, Outsourcing, and Wage Inequality", The American Economic Review, Vol. 86(2), pp. 240.245.

Feenstra, R. and Hanson, G. (1997): "Foreign Direct Investment and Relative Wages: Evidence from Mexico's Maquiladoras", Journal of International Economics, vol. 42, pp. 371-93.

Feliciano, Z. (2001): "Workers and Trade Liberalization: The impact of trade reforms in Mexico on wages and employment", Industrial and Labor Relations Review, Vol. 55, No. 1, 95-115.

Galbraith, J. K. and Kum, H. (2003): "Inequality and Economic Growth: A Global View based on Measures of Pay," CESifo Economic Studies, 49, 527-56, 2003 
Galbraith, J. K. and Kum, H. (2005): "Estimating the Inequality of Household Incomes: a Statistical Approach to the Creation of a Dense and Consistent Global Data Set", Review of Income and Wealth, Vol 51 (1), pp. 115-143.

Goldberg, P. and Pavcnik, N. (2001): "Trade Protection and Wages: Evidence from the Colombian Trade Reforms", NBER Working Paper No.8575, National Bureau of Economic Research, Cambridge (Mass.)

Görg H. and Strobl, E. (2001): "Relative Wages, Openness and Skill-Biased Technological Change in Ghana", CREDIT Research Paper, No. 01/18, CREDIT, University of Nottingham, Nottingham.

Grimalda, G. and Vivarelli, M. (2004): "One or Many Kuznets Curves? Short and Long Run Effects of the Impact of Skill-Biased Technological Change on Income Inequality", IZA discussion paper no. 1223, IZA, Bonn.

Grossman G. M. and Helpman, E. (1991): "Innovation and Growth in the Global Economy", MIT Press, Cambridge (Mass.).

Hanson, G. and A. Harrison (1999): "Trade and wage inequality in Mexico," Industrial and Labor Relations Review, Vol. 52(2), pp. 271-288

Judson, R. A. and Owen, A. L. (1999): "Estimating dynamic panel data models: a guide for macroeconomists", Economics Letters, vol. 65, 9-15

Kiviet, J.F. (1995): “On Bias, Inconsistency, and Efficiency of Various Estimators in Dynamic Panel Data Models", Journal of Econometrics, vol.68, pp.53-78.

Krugman, P. (1979): "A Model of Innovation, Technology Transfer, and the World Distribution of Income", Journal of Political Economy, vol.87, pp. 253-66

Kuznets, S. (1955): "Economic Growth and Income Inequality", American Economic Review, vol. 45, pp. 1-28.

Lall, S. (2004): “The Employment Impact of Globalization in Developing Countries", in Lee, E. and Vivarelli, M. (2004) (eds) “Understanding Globalization, Employment and Poverty Reduction”, Palgrave Macmillan, New York, pp. 73-101.

Lee, E. and Vivarelli, M. (2004) (eds.): “Understanding Globalization, Employment and Poverty Reduction”, Palgrave Macmillan, New York.

Lee, E. and Vivarelli, M. (2006a) (eds.): "Globalization, Employment and Income Distribution in Developing Countries", Palgrave Macmillan, New York.

Lee, E. and Vivarelli, M. (2006b): "The Social Impact of Globalization in Developing Countries", International Labour Review, Vol. 145 (3), pp. 167-184.

Li, H., Squire, L. and Zou, H. (1998): "Explaining International and Intertemporal Variation in Income Inequality", The Economic Journal, Vol. 108, pp. 26-43.

Lundberg, M. and Squire, L. (2003): "The Simultaneous Evolution of Growth and Inequality", Economic Journal, Vol.113 (487).

Machin, S. and Van Reenen, J. (1998): “Technology and Changes in Skill Structure: Evidence from Seven OECD Countries," Quarterly Journal of Economics 113: 4, pp. 1215-44.

Mayer, J. (2000): "Globalization, Technology Transfer and Skill Accumulation in Developing Countries", UNCTAD Discussion Paper, N.150, UNCTAD, Geneva. 
Melitz, M., (2003): "The Impact of Trade on Aggregate Industry Productivity and Intra-Industry Reallocations," Econometrica, Vol. 71 (6) pp. 1695-1725.

Milanovic, B. and Squire, L. (2005): "Does Tariff Liberalization Increase Wage Inequality? Some Empirical Evidence”, World Bank Policy Research Working Paper, No. 3571., World Bank, Washington, DC.

Montobbio, F. and F. Rampa (2005): “The Impact of Technology and Structural Change on Export Performance in Nine Developing Countries", World Development, Vol. 33 (4), pp. 527-547

Ravallion, M. (2001): “Growth, Inequality and Poverty: Looking beyond Averages", World Development, Vol.29 (11); pp. 1803-1815.

Robbins, D. (1996): "HOS Hits Facts: Facts Win; Evidence on Trade and Wages in the Developing World" OECD Technical Paper No. 119, OECD, Paris.

Robbins, D. (2003): "The impact of trade liberalization upon inequality in developing countries - A review of theory and evidence", ILO Working Paper, n.13, International Labour Organization, Geneva.

Robbins, D. and Gindling, T.H. (1999): “Trade Liberalization and the Relative Wages for More-Skilled Workers in Costa Rica", Review of Development Economics, 3(2), pp 140-154.

Rodrik, D. (1999): "Democracies Pay Higher Wages", The Quarterly Journal of Economics, Vol. 114 (3), pp. $707-738$

Sala-i-Martin, X. (2002): “The Disturbing 'Rise' of Global Income Inequality”, NBER Working Paper No. 8904, National Bureau of Economic Research, Cambridge (Mass.).

Schiff, M. and Wang, Y. (2006): "On the Quantity and Quality of Knowledge: the Impact of Openness and Foreign R\&D on North-North and North-South Technology Spillovers", in Hoeckman and Javoricik (2006) (eds): "Global Integration and Technology Transfer", Palgrave Macmillan and World Bank, New York and Washington, pp 99-112.

Verbeek, M. (2004) "A Guide to Modern Econometrics", Wiley, Chichester, 2nd edition.

Verhoogen, E. (2007): “Trade, Quality Upgrading and Wage Inequality in the Mexican Manufacturing Sector," IZA Discussion Paper, N. 2913, IZA, Bonn

Vivarelli, M. (2004): "Globalization, Skills and Within-Country Income Inequality in Developing Countries" in Lee, E. and Vivarelli, M. (2004) (eds): "Understanding Globalization, Employment and Poverty Reduction", Palgrave Macmillan, New York, pp: 211-243.

Wood, A. (1994): "North-South trade, employment, and inequality: Changing fortunes in a skill-driven world", Clarendon Press, Oxford.

Wood, A. and Ridao-Cano, C. (1999): "Skill, trade and international inequality", Oxford Economic Papers, Vol. 51, pp. 89-119.

Yeaple, S.R., (2005): “A Simple Model of Firm Heterogeneity, International Trade and Wages," Journal of International Economics, Vol. 65, pp. 1-20.

$\mathrm{Xu}$, B. (2003): "Trade liberalization, wage inequality, and endogenously determined non-traded goods," Journal of International Economics, Vol. 60, p. 417-431.

Zhu, S.C. and Trefler, D. (2005): "Trade and Inequality in Developing Countries: A General Equilibrium Analysis", Journal of International Economics, Vol. 65 (1), pp. 21-4 


\section{TABLES AND FIGURES}

Table 1

\begin{tabular}{lcccc}
\hline & \multicolumn{2}{c}{ 1980s } & \multicolumn{2}{c}{ 1990s } \\
Variable & Mean & Std. Dev. & Mean & Std. Dev. \\
\hline \hline & 38.48 & 23.33 & 48.58 & 30.94 \\
Trade (\% GDP) & 16.47 & 12.73 & 20.76 & 14.51 \\
Exp (\% GDP) & 22.01 & 13.41 & 27.82 & 18.08 \\
Imp (\% GDP) & 12.82 & 8.13 & 17.48 & 12.58 \\
Trade with DCs (\% GDP) & 25.66 & 18.54 & 31.10 & 21.86 \\
Trade with ICs (\% GDP) & 5.00 & 4.15 & 7.18 & 6.75 \\
Exp to DCs (\% GDP) & 11.47 & 10.80 & 13.58 & 10.18 \\
Exp to ICs (\% GDP) & 7.82 & 5.35 & 10.30 & 7.44 \\
Imp from DCs (\% GDP) & 14.19 & 10.07 & 17.53 & 13.09 \\
Imp from ICs (\% GDP) & 1907.13 & 1809.53 & 2476.03 & 2292.66 \\
GDP per capita & 67.43 & 614.55 & 93.58 & 507.36 \\
Inflation rate & 1.55 & 4.38 & 2.16 & 4.46 \\
HK & & & & \\
\hline
\end{tabular}

Tab 2: All Sample, different openness measures; dependent variable: EHII

(1)

\begin{tabular}{|c|c|c|c|c|c|c|}
\hline EHII (-1) & $\begin{array}{c}0.973 * * * \\
(17.8)\end{array}$ & $\begin{array}{c}0.952 * * * \\
(14.2)\end{array}$ & $\begin{array}{c}0.973 * * * \\
(18.0)\end{array}$ & $\begin{array}{c}0.953 * * * \\
(14.1)\end{array}$ & $\begin{array}{c}0.999 * * * \\
(19.7)\end{array}$ & $\begin{array}{c}0.965 * * * \\
(18.7)\end{array}$ \\
\hline TRADE & $\begin{array}{c}0.0140 * \\
(1.96)\end{array}$ & $\begin{array}{c}0.0144 \\
(1.04)\end{array}$ & & & & \\
\hline TRADE (-1) & & $\begin{array}{c}-0.000901 \\
(-0.057)\end{array}$ & & & & \\
\hline IMP & & & $\begin{array}{c}0.0114 * * \\
(2.06)\end{array}$ & $\begin{array}{c}0.0135 \\
(1.22)\end{array}$ & & \\
\hline $\operatorname{IMP}(-1)$ & & & & $\begin{array}{c}-0.000110 \\
(-0.0084)\end{array}$ & & \\
\hline EXP & & & & & $\begin{array}{c}0.00591 \\
(0.72)\end{array}$ & $\begin{array}{c}0.0128 \\
(0.93)\end{array}$ \\
\hline $\operatorname{EXP}(-1)$ & & & & & & $\begin{array}{c}-0.0107 \\
(-0.76)\end{array}$ \\
\hline GDP & $\begin{array}{c}-0.0148 \\
(-0.89)\end{array}$ & $\begin{array}{c}-0.0182 \\
(-0.85)\end{array}$ & $\begin{array}{c}-0.0141 \\
(-0.81)\end{array}$ & $\begin{array}{c}-0.0190 \\
(-0.87)\end{array}$ & $\begin{array}{c}-0.00797 \\
(-0.41)\end{array}$ & $\begin{array}{c}-0.00909 \\
(-0.36)\end{array}$ \\
\hline HK & $\begin{array}{c}-0.000545 \\
(-0.41)\end{array}$ & $\begin{array}{c}-0.000994 \\
(-0.45)\end{array}$ & $\begin{array}{c}-0.000543 \\
(-0.41)\end{array}$ & $\begin{array}{c}-0.00100 \\
(-0.46)\end{array}$ & $\begin{array}{c}-0.000387 \\
(-0.23)\end{array}$ & $\begin{array}{c}-0.000899 \\
(-0.44)\end{array}$ \\
\hline INFL & $\begin{array}{c}0.00603^{* *} \\
(2.32)\end{array}$ & $\begin{array}{c}0.00720^{* * * *} \\
\quad(2.84)\end{array}$ & $\begin{array}{c}0.00617^{* *} \\
(2.36)\end{array}$ & $\begin{array}{c}0.00744 * * * \\
\quad(3.01)\end{array}$ & $\begin{array}{c}0.00584^{* *} \\
(2.22)\end{array}$ & $\begin{array}{c}0.00683^{* *} \\
(2.51)\end{array}$ \\
\hline LTI & & $\begin{array}{l}0.282 \\
(0.64)\end{array}$ & & $\begin{array}{l}0.282 \\
(0.66)\end{array}$ & & $\begin{array}{l}0.059 \\
(0.18)\end{array}$ \\
\hline Observations & 686 & 638 & 686 & 638 & 685 & 637 \\
\hline Countries & 70 & 69 & 70 & 69 & 70 & 69 \\
\hline
\end{tabular}

Notes: absolute value of $\mathrm{z}$-statistics in brackets (bias correction initialised by Arellano-Bond estimator and bootstrapped standard errors): * significant at $10 \%$; ** significant at 5\%; *** significant at $1 \%$.

LTI is the Long-term Impact, z-statistics in brackets. 
Table 3: Disaggregating trade flows according to their origin/destination

\begin{tabular}{|c|c|c|c|c|c|c|}
\hline & (1) & (2) & (3) & (4) & (5) & (6) \\
\hline EHII (-1) & $\begin{array}{c}0.953 * * * \\
(16.3)\end{array}$ & $\begin{array}{c}0.890 * * * \\
(11.9)\end{array}$ & $\begin{array}{c}0.971^{* * *} \\
(18.0)\end{array}$ & $\begin{array}{c}0.934^{* * *} \\
(12.7)\end{array}$ & $\begin{array}{c}0.960^{* * *} \\
(14.5)\end{array}$ & $\begin{array}{c}0.909 * * * \\
(14.3)\end{array}$ \\
\hline TRADE_DC & $\begin{array}{c}-0.0141 \\
(-1.55)\end{array}$ & $\begin{array}{c}0.00470 \\
(0.47)\end{array}$ & & & & \\
\hline TRADE_IC & $\begin{array}{c}0.0305^{* * *} \\
(3.05)\end{array}$ & $\begin{array}{c}0.00634 \\
(0.40)\end{array}$ & & & & \\
\hline TRADE_DC $(-1)$ & & $\begin{array}{c}-0.0361^{* * *} \\
(-3.15)\end{array}$ & & & & \\
\hline TRADE_IC (-1) & & $\begin{array}{c}0.0393 * * \\
(2.34)\end{array}$ & & & & \\
\hline IMP_DC & & & $\begin{array}{c}-0.00297 \\
(-0.36)\end{array}$ & $\begin{array}{c}0.0150 \\
(1.54)\end{array}$ & & \\
\hline IMP_IC & & & $\begin{array}{c}0.0153 \\
(1.56)\end{array}$ & $\begin{array}{c}-0.00401 \\
(-0.32)\end{array}$ & & \\
\hline IMP_DC (-1) & & & & $\begin{array}{c}-0.0366 * * * \\
(-3.51)\end{array}$ & & \\
\hline IMP_IC (-1) & & & & $\begin{array}{c}0.0427 * * * \\
(3.56)\end{array}$ & & \\
\hline EXP_DC & & & & & $\begin{array}{c}-0.00904 \\
(-1.13)\end{array}$ & $\begin{array}{c}-0.00129 \\
(-0.19)\end{array}$ \\
\hline EXP_IC & & & & & $\begin{array}{c}0.0159 * * \\
(2.48)\end{array}$ & $\begin{array}{c}0.0168 \\
(1.41)\end{array}$ \\
\hline EXP_DC (-1) & & & & & & $\begin{array}{c}-0.0154 * * \\
(-2.20)\end{array}$ \\
\hline EXP_IC (-1) & & & & & & $\begin{array}{c}-0.00299 \\
(-0.22)\end{array}$ \\
\hline GDP & $\begin{array}{c}-0.0203 \\
(-1.24)\end{array}$ & $\begin{array}{c}-0.0270 \\
(-1.33)\end{array}$ & $\begin{array}{c}-0.0168 \\
(-0.95)\end{array}$ & $\begin{array}{c}-0.0288 \\
(-1.35)\end{array}$ & $\begin{array}{c}-0.0103 \\
(-0.54)\end{array}$ & $\begin{array}{c}-0.00813 \\
(-0.34)\end{array}$ \\
\hline HK & $\begin{array}{c}-0.000052 \\
(-0.041)\end{array}$ & $\begin{array}{c}-0.0000124 \\
(-0.0061)\end{array}$ & $\begin{array}{c}-0.000330 \\
(-0.25)\end{array}$ & $\begin{array}{c}0.000279 \\
(0.13)\end{array}$ & $\begin{array}{c}-0.000373 \\
(-0.23)\end{array}$ & $\begin{array}{c}-0.000857 \\
(-0.41)\end{array}$ \\
\hline INFL & $\begin{array}{c}0.00615^{* *} \\
(2.36)\end{array}$ & $\begin{array}{c}0.00704^{* * *} \\
(2.75)\end{array}$ & $\begin{array}{c}0.00622 * * \\
(2.35)\end{array}$ & $\begin{array}{c}0.00710^{* * * *} \\
(2.89)\end{array}$ & $\begin{array}{c}0.00598^{* *} \\
(2.29)\end{array}$ & $\begin{array}{c}0.00697 * * \\
(2.58)\end{array}$ \\
\hline LTI & & $\begin{array}{l}0.414 \\
(1.54)\end{array}$ & & $\begin{array}{l}0.584 \\
(0.90)\end{array}$ & & $\begin{array}{l}0.151 \\
(1.20)\end{array}$ \\
\hline Observations & 686 & 638 & 686 & 638 & 685 & 637 \\
\hline Countries & 70 & 69 & 70 & 69 & 70 & 69 \\
\hline
\end{tabular}

Notes: absolute value of z-statistics in brackets (bias correction initialised by Arellano-Bond estimator and bootstrapped standard errors): * significant at 10\%; ** significant at 5\%; *** significant at $1 \%$.

IC = Industrialised Countries; DC: Developing countries

LTI is the Long-term Impact, z-statistics in brackets.

The table only reports the LTI calculated on trade, imports and exports with/from/ to Industrialized Countries. 


\begin{tabular}{|c|c|c|c|c|c|c|}
\hline & (1) & (2) & (3) & (4) & (5) & (6) \\
\hline EHII $(-1)$ & $\begin{array}{c}0.945^{* * *} \\
(15.8)\end{array}$ & $\begin{array}{c}0.870 * * * \\
(12.5)\end{array}$ & $\begin{array}{c}0.965^{* * *} \\
(17.1)\end{array}$ & $\begin{array}{c}0.917 * * * \\
(13.0)\end{array}$ & $\begin{array}{c}0.943^{* * *} \\
(13.6)\end{array}$ & $\begin{array}{c}0.890^{* * *} \\
(14.4)\end{array}$ \\
\hline TRADE_IC*MIC & $\begin{array}{c}0.0342 * * * \\
(2.93)\end{array}$ & $\begin{array}{c}-0.00594 \\
(-0.30)\end{array}$ & & & & \\
\hline TRADE_IC*LIC & $\begin{array}{c}0.00979 \\
(0.49)\end{array}$ & $\begin{array}{c}0.0161 \\
(0.55)\end{array}$ & & & & \\
\hline TRADE_DC*MIC & $\begin{array}{c}-0.0162 \\
(-1.49)\end{array}$ & $\begin{array}{c}0.0183 \\
(1.45)\end{array}$ & & & & \\
\hline TRADE_DC*LIC & $\begin{array}{c}-0.00709 \\
(-0.43)\end{array}$ & $\begin{array}{c}-0.00539 \\
(-0.27)\end{array}$ & & & & \\
\hline TRADE_IC*MIC (-1) & & $\begin{array}{c}0.0594 * * * \\
(2.68)\end{array}$ & & & & \\
\hline TRADE_IC*LIC (-1) & & $\begin{array}{c}-0.00229 \\
(-0.074)\end{array}$ & & & & \\
\hline TRADE_DC*MIC $(-1)$ & & $\begin{array}{c}-0.0562 * * * \\
(-4.67)\end{array}$ & & & & \\
\hline TRADE_DC*LIC (-1) & & $\begin{array}{c}-0.000321 \\
(-0.016)\end{array}$ & & & & \\
\hline IMP_IC*MIC & & & $\begin{array}{c}0.0201^{*} \\
(1.93)\end{array}$ & $\begin{array}{c}-0.0158 \\
(-1.02)\end{array}$ & & \\
\hline IMP_IC*LIC & & & $\begin{array}{c}-0.00624 \\
(-0.34)\end{array}$ & $\begin{array}{c}-0.00246 \\
(-0.11)\end{array}$ & & \\
\hline IMP_DC*MIC & & & $\begin{array}{c}-0.00570 \\
(-0.65)\end{array}$ & $\begin{array}{c}0.0276^{* *} \\
(2.16)\end{array}$ & & \\
\hline IMP_DC*LIC & & & $\begin{array}{c}0.00237 \\
(0.15)\end{array}$ & $\begin{array}{c}0.00166 \\
(0.099)\end{array}$ & & \\
\hline IMP_IC*MIC (-1) & & & & $\begin{array}{c}0.0595 * * * \\
(4.05)\end{array}$ & & \\
\hline IMP_IC*LIC (-1) & & & & $\begin{array}{c}0.0205 \\
(0.94)\end{array}$ & & \\
\hline IMP_DC*MIC (-1) & & & & $\begin{array}{c}-0.0530 * * * \\
(-4.57)\end{array}$ & & \\
\hline IMP_DC*LIC (-1) & & & & $\begin{array}{c}-0.00997 \\
(-0.57)\end{array}$ & & \\
\hline EXP_IC*MIC & & & & & $\begin{array}{c}0.0215^{* *} \\
(2.54)\end{array}$ & $\begin{array}{c}0.0208 \\
(1.44)\end{array}$ \\
\hline EXP_IC*LIC & & & & & $\begin{array}{c}0.00258 \\
(0.19)\end{array}$ & $\begin{array}{c}0.00842 \\
(0.36)\end{array}$ \\
\hline EXP_DC*MIC & & & & & $\begin{array}{c}-0.0145^{*} \\
(-1.66)\end{array}$ & $\begin{array}{c}-0.00218 \\
(-0.26)\end{array}$ \\
\hline EXP_DC*LIC & & & & & $\begin{array}{c}0.00129 \\
(0.11)\end{array}$ & $\begin{array}{c}0.00184 \\
(0.16)\end{array}$ \\
\hline EXP_IC*MIC (-1) & & & & & & $\begin{array}{c}0.000526 \\
(0.035)\end{array}$ \\
\hline EXP_IC*LIC (-1) & & & & & & $\begin{array}{c}-0.0115 \\
(-0.39)\end{array}$ \\
\hline EXP_DC*MIC (-1) & & & & & & $\begin{array}{c}-0.0212 * * \\
(-2.42)\end{array}$ \\
\hline EXP_DC*LIC (-1) & & & & & & $\begin{array}{c}-0.00375 \\
(-0.29)\end{array}$ \\
\hline GDP PC & $\begin{array}{c}-0.0214 \\
(-1.32)\end{array}$ & $\begin{array}{c}-0.0281 \\
(-1.43)\end{array}$ & $\begin{array}{c}-0.0191 \\
(-1.06)\end{array}$ & $\begin{array}{c}-0.0294 \\
(-1.33)\end{array}$ & $\begin{array}{c}-0.00834 \\
(-0.43)\end{array}$ & $\begin{array}{c}-0.00609 \\
(-0.26)\end{array}$ \\
\hline HK & $\begin{array}{c}-0.00000585 \\
(-0.0046)\end{array}$ & $\begin{array}{c}0.000163 \\
(0.082)\end{array}$ & $\begin{array}{c}-0.000259 \\
(-0.20)\end{array}$ & $\begin{array}{c}0.000452 \\
(0.21)\end{array}$ & $\begin{array}{c}-0.000350 \\
(-0.22)\end{array}$ & $\begin{array}{c}-0.000852 \\
(-0.42)\end{array}$ \\
\hline INFL & $\begin{array}{c}0.00616^{* *} \\
(2.32)\end{array}$ & $\begin{array}{c}0.00681^{* * * *} \\
(2.65)\end{array}$ & $\begin{array}{c}0.00641^{* *} \\
(2.40)\end{array}$ & $\begin{array}{c}0.00717^{* * *} \\
(2.94)\end{array}$ & $\begin{array}{c}0.00577 * * \\
(2.19) \\
\end{array}$ & $\begin{array}{c}0.00664^{* *} \\
(2.47)\end{array}$ \\
\hline LTI & & $\begin{array}{c}0.410^{*} \\
(1.77)\end{array}$ & & $\begin{array}{l}0.525 \\
(1.14)\end{array}$ & & $\begin{array}{l}0.194 \\
(1.63)\end{array}$ \\
\hline Observations & 686 & 638 & 686 & 638 & 685 & 637 \\
\hline Countries & 70 & 69 & 70 & 69 & 70 & 69 \\
\hline
\end{tabular}


Notes: absolute value of $\mathrm{z}$-statistics in brackets (bias correction initialised by Arellano-Bond estimator and bootstrapped standard errors):

* significant at $10 \%$; ** significant at $5 \%$; *** significant at $1 \%$.

IC = Industrialised Countries; DC: Developing countries. MIC: Middle Income Countries; LIC: Low Income Countries

LTI is the Long-term Impact, z-statistics in brackets.

The table only reports the LTI calculated on trade, imports and exports with/from/ to Industrialized Countries when interacted with the MIC dummy.

\section{Figure 1}

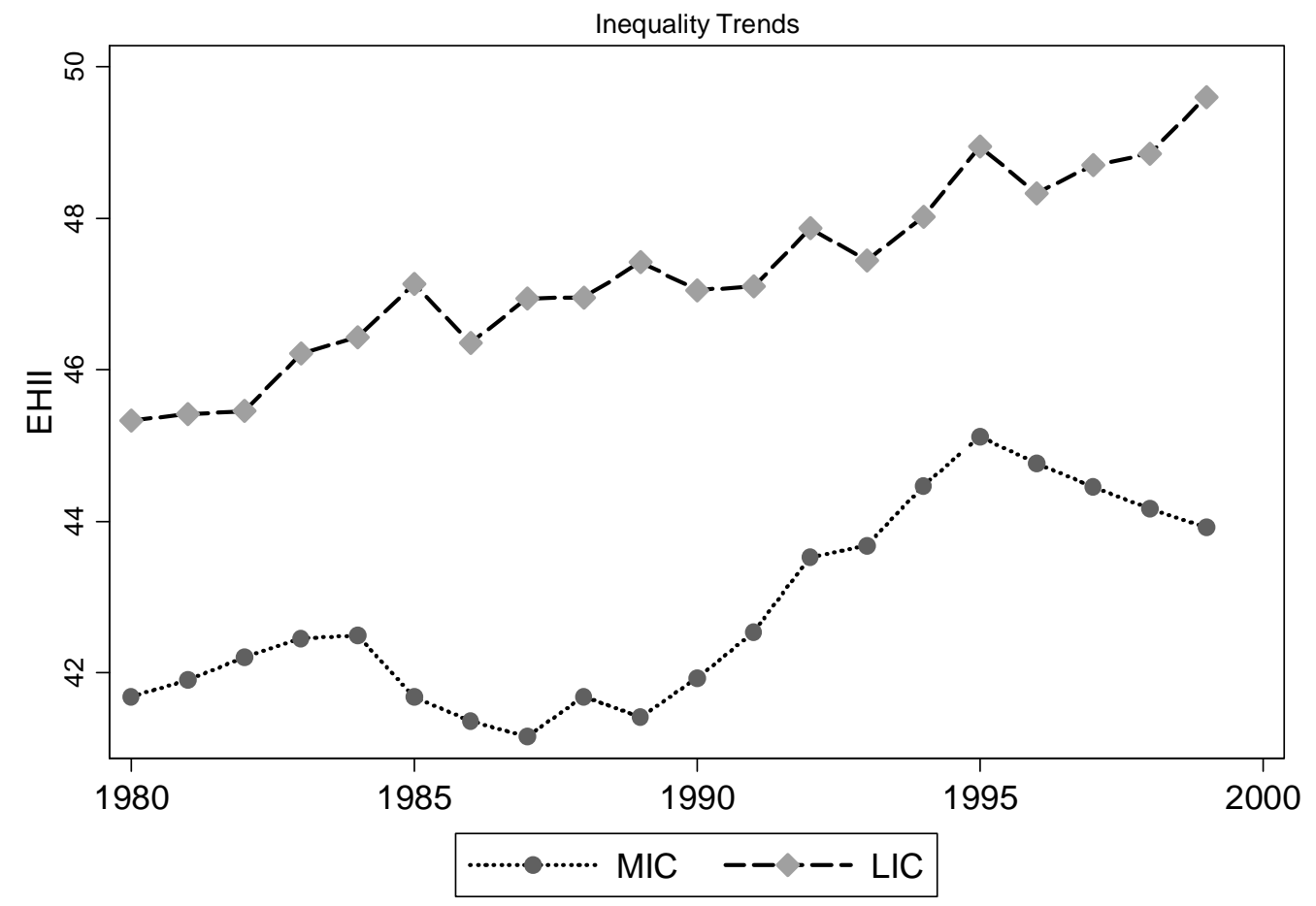




\begin{tabular}{|c|c|c|c|c|c|c|}
\hline Country & Years & Obs. & $\begin{array}{c}\text { Mean value } \\
\text { of EHII }\end{array}$ & $\begin{array}{l}\text { Initial } \\
\text { Value }\end{array}$ & $\begin{array}{l}\text { Final } \\
\text { Value }\end{array}$ & Change \\
\hline Algeria & 1980, 1984-97 & 15 & 38.19 & 35.52 & 40.45 & 4.93 \\
\hline Argentina & $1984-90,93-96$ & 11 & 43.95 & 41.13 & 45.24 & 4.11 \\
\hline Bangladesh & $1980-92$ & 13 & 44.61 & 40.45 & 48.44 & 7.99 \\
\hline Benin & 1980-81 & 2 & 47.65 & 48.39 & 46.91 & -1.48 \\
\hline Bolivia & 1980-99 & 20 & 48.92 & 43.73 & 50.49 & 6.76 \\
\hline Brazil & $1990,92-95$ & 5 & 47.02 & 45.22 & 47.49 & 2.27 \\
\hline Bulgaria & 1980-98 & 19 & 33.01 & 28.42 & 41.90 & 13.48 \\
\hline Burundi & $1980,83,86-91$ & 8 & 50.04 & 47.65 & 52.62 & 4.97 \\
\hline Cameroon & $1980-84,89-98$ & 15 & 53.82 & 46.73 & 56.39 & 9.66 \\
\hline Central African Republic & $1980-83,85-93$ & 13 & 47.59 & 41.06 & 51.98 & 10.92 \\
\hline Chile & $1980-99$ & 20 & 46.96 & 44.92 & 47.46 & 2.54 \\
\hline China & $1980-86$ & 7 & 31.49 & 30.19 & 32.81 & 2.62 \\
\hline Colombia & 1980-99 & 20 & 44.29 & 42.27 & 44.78 & 2.51 \\
\hline Congo, Rep. & $1981-88$ & 8 & 51.41 & 50.05 & 52.66 & 2.61 \\
\hline Costa Rica & 1984-98 & 15 & 41.29 & 46.94 & 39.91 & -7.03 \\
\hline Croatia & 1986-96 & 11 & 33.64 & 30.81 & 37.10 & 6.29 \\
\hline Cuba & 1980-89 & 10 & 31.01 & 32.53 & 30.16 & -2.37 \\
\hline Cyprus & 1980-99 & 20 & 39.34 & 40.59 & 40.15 & -0.44 \\
\hline Dominican Republic & $1980-85$ & 6 & 47.67 & 48.24 & 48.28 & 0.04 \\
\hline Ecuador & 1980-99 & 20 & 46.29 & 43.21 & 49.38 & 6.17 \\
\hline Egypt, Arab Rep. & $1980-99$ & 20 & 43.99 & 39.46 & 47.04 & 7.58 \\
\hline El Salvador & 1980-85, 93-98 & 12 & 45.74 & 42.48 & 46.29 & 3.81 \\
\hline Ethiopia & $1990-98$ & 9 & 44.09 & 40.87 & 44.88 & 4.01 \\
\hline Fiji & 1980-92, 96-98 & 16 & 45.06 & 43.23 & 42.75 & -0.48 \\
\hline Gambia, The & $1980-82$ & 3 & 46.40 & 45.59 & 47.54 & 1.95 \\
\hline Ghana & $1980-87,93-95$ & 11 & 52.23 & 51.65 & 53.17 & 1.52 \\
\hline Guatemala & $1980-88,91-95,97-98$ & 16 & 50.34 & 47.48 & 50.70 & 3.22 \\
\hline Haiti & $1980-88$ & 9 & 46.03 & 46.09 & 45.20 & -0.89 \\
\hline Honduras & $1981-95$ & 15 & 46.14 & 41.82 & 47.28 & 5.46 \\
\hline Hungary & 1980-99 & 20 & 32.66 & 26.41 & 39.43 & 13.02 \\
\hline India & 1980-99 & 20 & 49.06 & 50.25 & 49.60 & -0.65 \\
\hline Indonesia & $1980-98$ & 19 & 47.80 & 50.26 & 44.49 & -5.77 \\
\hline Iran, Islamic Rep. & $1980-93$ & 14 & 37.89 & 40.06 & 43.15 & 3.09 \\
\hline Jamaica & $1980,83-84,86-92$ & 10 & 53.04 & 53.66 & 55.26 & 1.60 \\
\hline Jordan & $1980-97$ & 18 & 47.40 & 45.12 & 46.44 & 1.32 \\
\hline Kenya & 1980-98 & 19 & 48.40 & 48.37 & 47.94 & -0.43 \\
\hline Korea, Rep. & 1980-99 & 20 & 37.39 & 38.83 & 37.75 & -1.08 \\
\hline Liberia & 1984-86 & 3 & 50.04 & 49.26 & 49.23 & -0.03 \\
\hline
\end{tabular}




\begin{tabular}{|c|c|c|c|c|c|c|}
\hline Country & Years & Obs. & $\begin{array}{c}\text { Mean value } \\
\text { of EHII }\end{array}$ & $\begin{array}{l}\text { Initial } \\
\text { Value }\end{array}$ & $\begin{array}{l}\text { Final } \\
\text { Value }\end{array}$ & Change \\
\hline Malawi & 1980-98 & 19 & 51.13 & 46.40 & 54.97 & 8.57 \\
\hline Malaysia & 1980-99 & 20 & 40.14 & 39.08 & 38.10 & -0.98 \\
\hline Malta & 1980-96 & 17 & 32.94 & 32.64 & 34.55 & 1.91 \\
\hline Mauritius & 1980-99 & 20 & 40.04 & 46.08 & 38.50 & -7.58 \\
\hline Mexico & 1980-99 & 20 & 43.32 & 42.07 & 45.20 & 3.13 \\
\hline Mozambique & $1990-96$ & 7 & 53.13 & 50.46 & 58.91 & 8.45 \\
\hline Nepal & 1986-91, 93-94, 96 & 9 & 47.45 & 46.21 & 44.26 & -1.95 \\
\hline Nicaragua & $1980-85$ & 6 & 42.12 & 42.93 & 41.61 & -1.32 \\
\hline Pakistan & 1980-91, 96 & 13 & 47.41 & 46.20 & 49.43 & 3.23 \\
\hline Panama & 1980-94, 96-98 & 18 & 47.13 & 43.44 & 48.56 & 5.12 \\
\hline Papua New Guinea & $1980-89$ & 10 & 51.20 & 49.69 & 52.06 & 2.37 \\
\hline Peru & 1982-92, 94 & 12 & 48.16 & 47.53 & 50.67 & 3.14 \\
\hline Philippines & 1980-97 & 18 & 47.01 & 43.05 & 48.04 & 4.99 \\
\hline Poland & 1980-99 & 20 & 32.55 & 28.95 & 42.50 & 13.55 \\
\hline Romania & 1990-94 & 5 & 28.98 & 24.77 & 32.12 & 7.35 \\
\hline Rwanda & $1984-86$ & 3 & 45.93 & 44.58 & 45.49 & 0.91 \\
\hline Senegal & 1980-97 & 18 & 45.73 & 40.01 & 49.61 & 9.60 \\
\hline Seychelles & $1980-86$ & 7 & 36.39 & 33.04 & 37.10 & 4.06 \\
\hline Slovak Republic & $1991-94,97-98$ & 6 & 33.57 & 29.50 & 36.25 & 6.75 \\
\hline Slovenia & $1987-98$ & 12 & 28.98 & 23.27 & 32.88 & 9.61 \\
\hline Sri Lanka & 1980-95 & 16 & 45.47 & 46.79 & 44.47 & -2.32 \\
\hline Syrian Arab Republic & $1980-98$ & 19 & 43.45 & 46.31 & 40.59 & -5.72 \\
\hline Thailand & $\begin{array}{l}1982,84,86,88-91 \\
93-94\end{array}$ & 9 & 46.60 & 49.30 & 41.76 & -7.54 \\
\hline Togo & $1980-84$ & 5 & 51.69 & 52.09 & 47.22 & -4.87 \\
\hline Trinidad and Tobago & $1981-95$ & 15 & 50.38 & 47.40 & 53.15 & 5.75 \\
\hline Tunisia & 1980-81, 93-98 & 8 & 48.18 & 44.00 & 48.36 & 4.36 \\
\hline Turkey & $1980-98$ & 19 & 45.07 & 44.48 & 46.99 & 2.51 \\
\hline Uganda & 1984-89 & 6 & 53.40 & 57.50 & 51.35 & -6.15 \\
\hline Uruguay & 1980-98 & 19 & 42.51 & 40.17 & 46.70 & 6.53 \\
\hline Venezuela, RB & $1980-96$ & 17 & 44.52 & 40.25 & 49.79 & 9.54 \\
\hline Zambia & $1980-82,90,94$ & 5 & 48.95 & 48.42 & 49.42 & 1.00 \\
\hline Zimbabwe & $1980-98$ & 19 & 45.37 & 44.44 & 47.44 & 3.00 \\
\hline
\end{tabular}




\section{Endnotes}

\footnotetext{
1 That is, the same technology and absence of scale economies.

${ }^{2}$ Other assumptions in the model are perfectly competitive markets and identical production functions with freely available technology across countries.
}

${ }^{3}$ Cline (1997), for examples, argues that "from the start, the SS and the factor price equalization theorems faced the major problems that they seemed radically divorced from reality" [Cline, 1997; p. 43]

${ }^{4}$ Cornia (2003) underlines the importance of this argument in explaining the increase in inequality that many middleincome countries have experienced during the '90s. He stresses that, as a consequence of the entry into the world market of low-skill manufactures from China, India, Indonesia and other exporters with substantially low wages, the formal sector of middle-income countries "no longer has a comparative advantage in labour-intensive exports and either it informalises its production via a long chain of subcontracting agreements or shifts production towards skillintensive exports. In both cases, wage inequality is likely to worsen” [Cornia, 2003, p.605].

${ }^{5}$ This hypothesis is now common in standard models of international trade such as those provided by Krugman (1979), and Grossman and Helpman (1991).

${ }^{6}$ Foreign direct investments are also important vehicles of international technology diffusion. However, the treatment of their role is beyond the scope of this work.

${ }^{7}$ Foreign knowledge is defined as the sum of trading partners' R\&D stocks (that is a measure of knowledge quality), weighted by bilateral trade shares (a measure of knowledge quantity).

${ }^{8}$ They proxy the technological complexity of a machinery by its average unit value.

${ }^{9}$ For possible recursive and cumulative relationships between technology, skills and exports, see Montobbio and Rampa (2005) and Alvarez (2007)

${ }^{10}$ Statistically insignificant results emerge for low-income countries.

${ }^{11}$ For instance, Robbins and Gindling (1999) using household survey data for Costa Rica found that wage inequality increased after trade liberalization. Goldberg and Pavnik (2001) and Attanasio et al. (2004) reached similar conclusion for Colombia, using household survey data. Arbache, Dikerson and Green (2003) showed that in Brazil the influx of new skill intensive technologies, boosted by trade liberalization, contributed to the rise in the university education premium. For Mexico, several empirical works have shown that trade liberalization went hand-in-hand with rising wage inequality: using household data, Feliciano (2001) found that the increase in wage inequality was much greater in the tradable sectors than in the non-tradable ones. Cragg and Epelbaum (1996) have shown that the skill premium increased by about 68 per cent during the liberalization period. Using plant level data, Hanson and Harrison (1999) also found evidence for rising wage inequality following the reduction of trade barriers. Görg and Strobl (2001), analysing a panel of manufacturing firms in Ghana, also found that returns to skills increased after trade liberalization. Similar discoveries were made by Robbins (1996) for Argentina, Chile, Colombia, Costa Rica, Malaysia, Mexico, Philippines and Uruguay. Other studies jointly consider other determinants of inequality, together with trade openness (see, for instance, Chamarbagwala, 2006, on the Indian case).

${ }^{12}$ These studies generally vary in their conclusions according to different kinds of factors. First, they cover different countries and time periods. Second, the very definition of globalization is ambiguous: some papers measure globalisation looking at trade (and/or FDI) outcomes, while others focus on liberalization policies, such as 
decreasing tariffs or quotas. Third, different econometric specifications have been used. Most researchers estimate the relationship between inequality and openness by regressing levels on levels, while others have focused on changes in both the dependent and the explanatory variables (for a critical discussion of the different approaches, see Lee and Vivarelli 2004 and 2006a).

$13 \mathrm{AR}(1)$ has been computed using the fixed effect estimator.

${ }^{14}$ Least Square Dummy Variable Corrected.

15 Monte Carlo experiments (see Kiviet, 1995; Judson and Owen, 1999; Bun and Kiviet, 2003) show that the LSDVC estimator, in small samples, outperforms consistent IV-GMM estimators such as the Anderson-Hsiao and Arellano-Bond.

16 In particular, with an increasing level of accuracy: $B_{1}=c_{1}\left(T^{-1}\right) ; \quad B_{2}=B_{1}+c_{2}\left(N^{-1} T^{-1}\right)$; $B_{3}=B_{2}+C_{3}\left(N^{-1} T^{-2}\right)$.

${ }^{17}$ It should be noted that the three alternative procedures are asymptotically equivalent.

18 The data are available at http://utip.gov.utexas.edu

19 The original data come from UNIDO (United Nations Industrial Development Organization) statistics which provides average manufacturing pay by industries. The comparability and accuracy of the UNIDO compilation of employees and payment measures have recently been endorsed by Rodrik (1999) and Berman and Machin (2000 and 2004).

${ }^{20}$ Deninger and Squire (1996) collected many disparate surveys of income and expenditure inequality and compiled them into a single panel, offering 693 country/year observations since 1947.

${ }^{21}$ Atkinson and Brandolini (2001) present a critique of the D\&S database that focuses, in part, on the fact that many different types of data drawn from different sources are mixed up in the data set. In general, they criticize the use of "secondary" statistics and show how both cross-country comparisons and time-series analyses may crucially depend on the choice of data.

${ }^{22}$ The WIID is a comprehensive database built by the World Institute for Development Economics Research (WIDER), based at the United Nations University in Helsinki. It includes Deininger and Squire's (1996) dataset, and it is regularly extended and updated.

${ }^{23}$ For example, Vivarelli (2004) restricts the analysis to Gini Indexes based on nationally representative surveys and uses dummy variables to check for the remaining differences in the type of surveys; Bensidoun et al. (2005) uses only changes in Gini indexes based on the same income concept and reference unit within each country.

${ }^{24}$ The other variables included in the regression are the ratio of manufacturing employment to population, the share of urban population, and population growth rate. See Galbraith and Kum (2005), p. 126 for a theoretical justification of the choice of variables.

${ }^{25}$ We defined the income groups following the 1987 World Bank Classification which divides economies according to their per capita gross national income, calculated using the World Bank Atlas Method (See http://web.worldbank.org/WBSITE/EXTERNAL/DATASTATISTICS/0 „, contentMDK:20420458 menuPK:641 33156 pagePK:64133150 piPK:64133175 theSitePK:239419,00.html). We have chose 1987, because it is the year closest to the median of our data time distribution.

${ }^{26}$ In particular, the data used here refer to the educational attainment of the population aged 25 and over. 
${ }^{27}$ Inflation is measured by the annual growth rate of the GDP implicit deflator and shows the rate of price change in the economy as a whole. The GDP implicit deflator is the ratio of GDP in current local currency to GDP in constant local currency.

28 Only the one period lag is displayed in the tables, since lags of higher orders have never come out significant (results available under request). The long term impact (LTI) has been computed as the sum of the estimated coefficients of the contemporaneous and lagged openness variable over: 1- @ (long-run multiplier, see Verbeek, 2004, p.311).

${ }^{29}$ We also tried to use a different measure of human capital in order to account for the increase in post-primary education, but no significant changes occurred (results available under request). .

${ }^{30}$ This is a further confirmation of the need for a dynamic specification.

${ }^{31}$ Notice that the lag plays a role in the import but not in the export flows towards ICs. This might be due to the fact that imported technologies need some time to exert their skill biased effect, while the quality of exporting goods immediately implies an increase in the demand for local skilled workers.

${ }^{32}$ Indeed, the authors have found that the 'absorptive capacity' of a country (the ability to master a new technology) affects the choice of the type and age of the imported machineries.

${ }^{33}$ These findings are consistent with Berman and Machin's results (2000 and 2004): in fact, when studying the international diffusion of SBTC, they found evidence for SBTC being rapidly transferred from developed to middle income countries, while no results emerged for the low income group of countries. 